\title{
Fish or n3-PUFA intake and body composition: \\ A systematic review and meta-analysis
}

Nicole Bender ${ }^{1,2}$, Marc Portmann ${ }^{1}$, Zina Heg ${ }^{1}$, Karen Hofmann ${ }^{1}$, Marcel Zwahlen ${ }^{1}$ Matthias Egger ${ }^{1}$

${ }^{1}$ Institute of Social and Preventive Medicine, University of Bern, Finkenhubelweg 11, 3012 Bern

${ }^{2}$ Institute for Human Evolution, University of the Witwatersrand, 1 Yale Road, Johannesburg, South Africa

Keywords: body composition, fish, n3-PUFA

Running title: fish and body composition

Acknowledgements: The authors are grateful to Dr. Kali Tal for English editing.

Corresponding author: Nicole Bender, ISPM Bern, Finkenhubelweg 11, 3012 Bern, Switzerland, nbender@ispm.unibe.ch

\section{Conflicts of interest: none}




\section{Abstract}

Obesity is a major public health issue and an important contributor to the global burden of chronic disease and disability. Studies indicate that fish and omega 3 polyunsaturated fatty acids (n3-PUFA) supplements may help prevent cardiovascular and metabolic diseases. However, the effect of fish-oil on body composition is still uncertain, so we performed a systematic review of randomized controlled trials and the first meta-analysis on the association between fish or fish oil intake and body composition measures. We found evidence that participants taking fish or fish oil lost $0.59 \mathrm{~kg}$ more body weight than controls (95\% CI: -0.96 to -0.21 ). Treatment groups lost $0.24 \mathrm{~kg} / \mathrm{m} 2$ (BMI) more than controls (-0.40 to -0.08$)$, and $0.49 \%$ more body fat than controls (-0.97 to -0.01$)$. Fish or fish oil reduced waist circumference by $0.81 \mathrm{~cm}(-1.34$ to -0.28$)$ compared to control. There was no difference for fat mass and lean body mass. Further research is needed to confirm or refute our findings and to reveal possible mechanisms by which n3-PUFAs might reduce weight. 


\section{Introduction}

Obesity is a major public health issue and an important contributor to the global burden of chronic disease and disability (1). For more than two decades, the prevalence and incidence of obesity worldwide has reached pandemic proportions $(1,2)$. Its association with deleterious outcomes such as type 2 diabetes, heart disease, and depression, and its direct relation to increased all-cause mortality and reduced life expectancy $(1,3,4)$ make it a pressing global health problem.

Attempts to control the epidemic of obesity usually target behaviour and environmental aspects of the problem. World Health Organization strategy consists of a range of long-term measures, including primary prevention, weight maintenance, management of complications and weight loss (5). However, the global obesity epidemic continues despite these measures, indicating that new approaches are needed.

A much-debated approach is consumption of omega 3 polyunsaturated fatty acids (n3-PUFA, including eicosapentaenoic acid, EPA, and docosahexanoic acid, DHA), either through eating fish (which contain n3-PUFA) or taking supplements in the form of fish oil capsules. There is a growing evidence that n3-PUFA have beneficial effects on health, including prevention of cardiovascular diseases like stroke and coronary heart disease $(6,7)$, and metabolic diseases like dyslipidemia $(8,9)$. However, the influence of n3-PUFA on body composition is unclear.

Ecological studies in several countries indicate that a diet rich in fish is associated with low body weight (10). Several clinical studies suggest that fish oils and n3-supplements support weight-loss diets $(11,12)$, but the benefit was not evident in other studies $(13,14)$. A narrative review of these studies supported the argument that n3-PUFA may reduce obesity (15), while a systematic review of clinical trials that assessed the effects of dietary n3-PUFA on body weight in adults reported that four out of five studies did not show any important change (16). Only few randomized controlled trials assessed the influence of whole fish, and therefore a combination of fish oil and fish protein, on weight loss. These studies showed a similar effect of whole fish compared to fish oil, even when lean 
fish was used, suggesting a potential role of fish protein in weight loss (17-19). To date, no metaanalysis on this subject has been done.

We undertook a systematic review and meta-analysis of randomized controlled trials to assess the evidence for an effect of fish or fish-oil on body composition.

\section{Methods}

\section{Databases and search strategy}

We conducted and reported the present meta-analysis according to the Cochrane Handbook of Systematic Reviews on Interventions (20) and the PRISMA guideline (21). We searched the electronic databases Medline, Embase and the Cochrane Central Register of Controlled Trials (CENTRAL) (search last updated on 1 May 2013). The search strategy was combined for all exposures and outcomes of interest. Search terms included Fish, seafood, salmon, tuna, cod, anchovy, bass, bream, dogfish, eel, haddock, halibut, herring, huss, mackerel, monkfish, mullet, plaice, red snapper, rock, sardines, pilchards, skate, sole, swordfish, trout, turbot, $n 3$ fatty acid, $n 3$ supplement*, $n 3$ pufa, n3 polyunsaturated fatty acid, omega-3, eicosapentaenoic acid, EPA, docosahexanoic acid, DHA, and were combined with terms related to body composition: obesity, adiposity, body mass index, BMI, weight, waist, waist-to-hip ratio, WHR, fat, adipose, overweight, Quetelet index, diet, body composition. Where possible, we used MeSH headings (or other standardized indexing terms). The search was restricted to humans, but unrestricted for publication date or language (see supporting information document S1 for Medline search strategy. Search strategies for Embase and CENTRAL were similar). The reference lists of all included studies were examined to identify studies not found by the search of electronic databases. The references of all studies found were entered into an electronic database (Reference Manager, version 12, Thompson Reuters) and duplicates were removed. 


\section{Eligibility criteria}

The titles and abstracts of retrieved references were checked for inclusion or exclusion, according to the following pre-established criteria. We included randomized controlled trials in men or women and individuals of any ethnicity that reported body composition measures as primary or secondary outcomes. The exposures were fish or n3-PUFA derived exclusively from fish. Outcome measures were BMI, body fat percentage, body weight, waist circumference, hip circumference, waist-to-hipratio, lean body mass, or other measures of body composition. We excluded studies that used n3PUFA from vegetal sources, and RCTs with a crossover design that did not report results at crossover. We also excluded studies that aimed to increase body weight for cachectic patients $(22,23)$ or newborns $(24,25)$. See flowchart in Figure 1 for details on the identification of eligible studies. Two independent reviewers (NB, MP) assessed eligibility and reached consensus by discussion.

\section{Data extraction}

Two independent reviewers (NB, MP, ZH or KH) extracted data from the full text papers on all studies included. The reviewers used a standard data extraction sheet, entered in duplicate into an electronic database (EpiData, version 3.1, Copenhagen, Denmark). Discrepancies were resolved by discussion. Bibliographic details (author, publication year), details of the population (e.g., sex, age, setting), sample size per comparison group and number of people lost to follow up, exposure (fish or n-3 capsules) and daily dosage, obesity-related phenotypes (e.g. BMI, waist circumference) before and after the intervention were all extracted. Furthermore, potential confounders accounted for and quality criteria like type of randomization or blinding of participants and outcome assessors were extracted.

\section{Study quality}

To assess the internal validity of the studies and the accuracy of reporting we followed published guidelines to a priori identify criteria that may be related to the risk of bias $(26,27)$ : sequence generation, concealment of allocation, blinding of participants, blinding of clinicians, blinding of 
outcome assessor, and intention-to-treat analyses. For each included study we noted whether the quality criteria were met or not, or if they were not described.

\section{Data analysis}

We combined data using fixed effects meta-analyses. We calculated mean differences in changes from baseline between the two comparison groups, with 95\% confidence intervals. Standard deviations of changes from baseline were consistently reported only in three studies $(18,28,29)$. Where standard deviations of changes from baseline were missing, we used the formula provided in the Cochrane Handbook of Systematic Reviews (20) to calculate standard errors and then converted them into standard deviations. In this formula we used a correlation coefficient of 0.8 for the outcome lean body mass, and 0.9 for the other outcomes, as reported in the studies.

Statistical evidence for heterogeneity between studies was assessed by the $\mathrm{I}^{2}$ statistic (30). Funnel plots were used to examine possible small study bias; we used a regression test to test for funnel plot asymmetry (31). We also performed stratified analyses and random-effects meta-regressions to assess the effect of study quality criteria, patient characteristics and intervention characteristics on the results. The statistical package Stata (version 11.2, Stata Corp. College Station, TX) was used for all analyses.

\section{Results}

\section{Study selection}

We found 988 unique studies. After exclusions according to our criteria, we retrieved 38 studies as full text. Of these, 17 studies met the inclusion criteria, and we used 15 in the meta-analyses. We excluded two studies that reported results not in a format suited for meta-analysis. One (17) reported the outcomes as percentage of changes from baseline. This study showed no difference in body weight, waist circumference, fat mass and lean body mass between the fish-group and the control-group after a 8-week diet. The other study (32) reported outcome data (BMI and waist circumference) as median and interquartile ranges. It showed no difference between intervention and control group after three years of follow-up. 


\section{Study characteristics of included studies}

Most studies were conducted in European countries (8 studies). Three were carried out in Australia, two in North America, two in Asia and one each in South America and in Africa (see Table 1 for a description of included studies). The populations studied were mainly Caucasian. Most participants were recruited from general populations; four were from hospital or outpatient populations. Sample sizes varied between 18 and 563, but were mostly smaller than 100. A total of 934 participants were included. Study duration varied between three weeks and three years; most studies lasted two to three months. Exposure was mostly through n3-PUFA capsules, which contained both EPA and DHA in different ratios. The daily dosage of total n3-PUFA varied between $157 \mathrm{mg}$ and $3360 \mathrm{mg}$.

Quality criteria (sequence generation, concealment of allocation, blinding of participants, clinician or outcome assessor, intention-to-treat analysis) appeared to have no effect on results. But the reporting quality of most studies was low (see Table 2), which made it difficult to determine the impact of study quality on our results. Only six studies reported on sequence generation, five on concealment of allocation, no study reported whether or not outcome assessors were blinded, and only three studies reported that they performed an intention-to-treat analysis.

We did not find evidence for publication bias (see supporting information document S2). The regression test (body weight: $\mathrm{p}=0.31$; $\mathrm{BMI}$ : $\mathrm{p}=0.63$ ) did not indicate publication bias.

\section{Results of meta-analyses}

We gathered data suitable for meta-analyses for six different outcomes (body weight, BMI, body fat percentage, fat mass, waist circumference, and lean body mass). In general, meta-analyses showed a more pronounced change in body composition in intervention groups than in control groups (igure 2 and supporting information document S3). The heterogeneity between studies assessed by $\mathrm{I}^{2}$ statistics was $0 \%$ for all meta-analyses performed.

The meta-analysis of outcome body weight (12 studies) showed more weight loss in the intervention groups than in the control groups $(-0.59 \mathrm{~kg}, 95 \% \mathrm{CI}$ : -0.96 to $-0.21, \mathrm{p}=0.002)$. For the outcome BMI 
163 (13 studies), the meta-analysis showed a greater decrease in BMI in the intervention groups than in the control groups $\left(-0.24 \mathrm{~kg} / \mathrm{m}^{2}, 95 \% \mathrm{CI}:-0.40\right.$ to $\left.-0.08, \mathrm{p}=0.003\right)$. Similarly, for the outcome body fat percentage (7 studies), the meta-analysis showed a greater decrease in the intervention groups than in the control groups $(-0.49 \%, 95 \% \mathrm{CI}:-0.97$ to $-0.01, \mathrm{P}=0.047)$. Outcome waist circumference (7 studies) was also reduced more in the intervention groups than in the control groups $(-0.81 \mathrm{~cm}, 95 \%$ CI: -1.34 to $-0.28, \mathrm{p}=0.003)$.

For the outcome fat mass (3 studies), the meta-analysis showed no statistically significant difference between intervention and control groups $(-0.36 \mathrm{~kg}, 95 \% \mathrm{CI}$ : -0.96 to $0.24, \mathrm{p}=0.24)$. Similarly, for the outcome lean body mass (3 studies), the meta-analysis showed no statistically significant difference between intervention and control groups $(-0.19 \mathrm{~kg}, 95 \% \mathrm{CI}$ : -0.72 to 0.33 , $\mathrm{p}=0.47)$.

\section{Sensitivity analyses and meta-regressions}

Results were not modified by exposure characteristics (type of exposure (fish or fish oil), EPA/DHA ratio, dose per day, study time or additional interventions like calorie restricted diet or exercise), or participant characteristics (ethnicity, setting, age, nutritional stage, health condition, sex). We found that length of study (less than 60 days versus more than 60 days) had a significant effect in the metaregression for the outcome BMI ( $\mathrm{p}=0.028$ ): the effect was stronger in shorter studies (see also Figure 3). Stratified analyses by sex showed stronger effects of n3-PUFA on reduction of obesity related measures in males than in females, but this difference generally did not reach statistical significance ( $>0.17)$. An exception was waist circumference $(p=0.050)$ : the meta-regression showed a stronger effect in men than in women (based on 3 studies).

\section{Discussion}

We found evidence that intake of fish or fish oil capsules can decrease weight in adults. When considered on their own, most studies did not show a statistically significant difference: our metaanalyses documented effects that previous reviews had not detected $(15,16)$. We included only RCTs that explicitly examined body composition related measures as primary or secondary outcomes and 
used n3-PUFA of fish provenience. Our analysis was therefore not compromised by the possibility that n3-PUFA derived from vegetal sources had different effects than n3-PUFA derived from fish (33). Our study was, however, limited by poor reporting in the studies we examined. This made it difficult to assess the impact of study quality on results.

The effect found in our meta-analyses was modest: 590 grams mean difference in body weight between intervention and control groups. This finding was consistent for other body composition related outcomes like BMI, body fat percentage and waist circumference. For outcomes body fat mass and lean body mass, the direction of results was the same. However, results were not statistically significant, probably because of a lack of statistical power, as only few studies reported on these outcomes.

A modest weight loss of $5-10 \%$ body weight has been shown to be effective in improving risk factors like hyperinsulinemia, hypertension and dyslipidemia (34-36). Indeed, Klein concluded that modest weight loss can affect the whole cluster of cardiovascular risk factors simultaneously (37). Troseid and colleagues (32) found that despite small to moderate decreases in BMI, triglycerides and inflammatory markers such as IL-18 decreased after an n3-PUFA intervention, and an overall positive effect was obtained, probably by a combination of mechanisms. As obesity is associated with a low-grade inflammation state with mild elevation of several inflammatory markers expressed in adipose tissue, like TNF- $\alpha$ or IL-6 (38-40), the anti-inflammatory effect of n3-PUFA might have a beneficial effect. In fact, n3-PUFA was shown to reduce insulin resistance in rats and humans $(41,42)$ and proposed as a potential anti-inflammatory strategy to decrease obesity-related disease (43).

At a population level the effect of a small change in a risk factor on an outcome can be substantial. This phenomenon is known as the "prevention paradox" (44) and relates to the fact that a large number of people exposed to a low risk produce more cases of disease than a small number of people exposed to a high risk. In fact, the population attributable risk depends on the individual attributable risk and the prevalence of the risk factor in the population. It is therefore more effective to shift the distribution of the risk factor (in this case overweight) in the whole population, than to treat only those at high risk (obese people), even if the shift in the population is modest. We found that taking n3-PUFA for less 
than two months may be more effective than longer interventions. This finding questions the long term effect of n3-PUFA on body composition, but as only few studies lasted longer than two months and only one study lasted more than a year (32), more long-term studies are needed to clarify this point.

In the present study, we found some indications that the effect might be greater in males than in females for the outcome waist circumference, which is a measure for visceral adiposity. This is relevant, as visceral fat is strongly associated with metabolic disease risks (45-47). Several studies reported that n3-PUFA had a stronger effect on weight loss in males than in females (e.g. (18)), while other studies found stronger effects in women (12). Difference between the sexes in the physiological response to n3-PUFA is plausible because men and women have a different fat tissue anatomy and physiology. For example, women may convert more alpha-linoleic acid into DHA than men do (48, 49). A population based study in New Zealand showed higher DHA levels and lower EPA levels in serum lipids in females compared to males (50). Future studies on the effect of n3-PUFA on body composition should examine gender differences in order to clarify possible differences in health benefits.

A further question is the relative importance of EPA and DHA. We did not find a dose-response relationship or an effect modification depending on the EPA / DHA ratio, despite both animal studies $(51,52)$ and human studies (28) suggesting this possibility. Several mechanisms have been proposed to explain the weight loss effect of n3-PUFA, for example increased lipolysis and reduced lipogenesis. In rodents (53) and in humans (54) n3-PUFA stimulate beta-oxidation, and inhibit fatty acid synthesis and VLDL secretion, partially by regulating gene expression. In rats, there is indication that n3-PUFA might reduce lipogenesis in adipose cells by reducing lipoprotein lipase (LPL) activity (55). In addition to n3-PUFA, fish protein might have an effect on body weight. For example, the amino acid taurine, which is abundant in fish protein, showed a weight lowering effect in mice $(56,57)$ and humans (58). In our meta-regressions, we did not find a difference between the effects of whole fish or of fish oil on body composition. However, only three studies included in our analysis used whole fish as exposure $(17,18,59)$, so that more studies are needed using whole fish or fish protein to clarify the possible specific roles of fish oil and fish protein, and the different components of fish protein. 
244 Our meta-analysis and other studies showed that n3-PUFA might influence body composition and 245 health in a favorable way. Evolutionary considerations are also relevant in this context. Based on 246 estimates from studies on Paleolithic nutrition and modern-day hunter-gatherer populations it seems

247 likely that humans have evolved with a diet that contained small and approximately equal amounts of 248 n6 and n3-PUFA and lower amounts of trans-fatty acids and linoleic acid (60). A nutrition rich in n3249 PUFA and other nutrients typical for the Paleolithic diet, such as polyphenols, fiber, and plant sterols, 250 was therefore proposed to improve health outcomes (61). Of several early Homo species (such as

251 Homo habilis, Homo erectus and early Homo sapiens) it is assumed that they consumed fish and 252 seafood (62-64). However, the exploitation of aquatic food resources is still a neglected field in 253 paleoanthropology $(65,66)$ and more research on the reconstruction of our ancient natural nutrition, 254 including aquatic food, is needed (67). This knowledge should contribute to a better understanding of 255 modern human nutrition and health.

\section{Conclusions}

Our meta-analysis showed that consumption of n3-PUFA can decrease weight in adults. Further research is needed to reveal which components of fish and fish oil are most beneficial. In particular, the documented positive effects of n3-PUFA on cardiovascular diseases, dyslipidemia and obesity suggest that we should continue to explore the effects of fish-derived n3-PUFA on human health. 


\section{Table legends}

263 Table 1: Characteristics of studies included in the systematic review. Country and setting of the 264 studies are given, as well as sample size per group, exposure used, and duration of studies. All except 265 Abete 2009 and Troseid 2009 were included in the meta-analyses.

266 Table 2: Quality criteria of studies included in the systematic review. The criteria chosen were: correct method of randomization, correct concealment of allocation, blinding of participants, clinicians and outcome assessors, and the application of an intention-to-treat data analysis. For each study it was

269 stated if the criterion was met or not, or if it was not described (classified as unclear). Criteria that 270 were not possible to meet (e.g., blinding for fish meals) were classified as non applicable. 
274 Figure 1: Flow chart of studies throughout the systematic review process. Numbers of studies found, selected and included or excluded were given for each review step, with reasons for exclusion in full text studies.

Figure 2: Results of meta-analyses performed for different outcomes on the association between fish or fish oil intake and body composition. The number of datasets can be higher than the number of studies included, if some studies reported their results divided into subgroups (as for instance by intervention type or by sex). The mean differences between intervention and control groups and their 95\% confidence intervals are given for each outcome. Note that the unit of measure for each outcome is different.

Figure 3: Forest-plot of meta-analysis on the association between fish or fish oil and BMI, by time of study duration. Studies are divided into two groups: less than two months of study duration vs. more than two months of study duration. Only studies of less than two months of study duration show a BMI-lowering effect of fish or fish oil. 


\section{Supporting information}

290 Supporting information document S1: Search strategy for the database Medline. The search strategies for the databases Embase and CENTRAL were similar.

Supporting information document S2: Figure showing funnel plots of studies for the outcomes body weight (12 studies) and BMI (13 studies). There was no indication for publication bias.

Supporting information document S3: Forest plots of meta-analyses on the association between fish oil intake and body composition measures. Figure 1 shows the results for the outcome body weight, Figure 2 for the outcome BMI. Figure 3 shows the results for the outcome body fat percentage, Figure 4 for the outcome waist circumference. Figure 5 shows the results for the outcome fat mass, Figure 6 for the outcome lean body mass. For all outcomes the weighted mean difference between changes from baseline comparing intervention group and control group and 95\% confidence intervals are given, as well as overall estimates. All meta-analyses were performed as fixed effects models, as no one showed evidence for heterogeneity. 
Published in final edited form as: Obes Rev. 2014 Aug;15(8):657-65. doi: 10.1111/obr.12189

305 
Table 1: Characteristics of studies

\begin{tabular}{|c|c|c|c|c|c|c|}
\hline Reference & Country & Setting or population & $\begin{array}{l}\text { Intervention } \\
\text { group (N, \% } \\
\text { males) }\end{array}$ & $\begin{array}{l}\text { Control } \\
\text { group }(\mathrm{N}, \\
\% \text { males) }\end{array}$ & $\begin{array}{l}\text { Exposure, per } \\
\text { day }(\mathrm{mg}): \text { EPA / } \\
\text { DHA }\end{array}$ & $\begin{array}{l}\text { Duration of } \\
\text { study } \\
\text { (days) }\end{array}$ \\
\hline $\begin{array}{l}\text { Abete } 2009 \\
(17) \dagger\end{array}$ & Spain & General population & $8(100 \%)$ & $10(100 \%)$ & $\begin{array}{l}3 \text { meals with fatty } \\
\text { fish weekly }\end{array}$ & 56 \\
\hline $\begin{array}{l}\text { Bays } 2009 \\
(29)\end{array}$ & USA & Unclear & $84(71 \%)$ & $83(76 \%)$ & $1860 / 1500$ & 56 \\
\hline $\begin{array}{l}\text { Crochemore } \\
2012(14)\end{array}$ & Brazil & $\begin{array}{l}\text { Hospital, high blood } \\
\text { pressure and diabetes } \\
\text { program }\end{array}$ & $28(0 \%)$ & $13(0 \%)$ & $\begin{array}{l}\text { A: } 547.5 / 352.5 \\
\text { B: } 328.5 / 211.5\end{array}$ & 30 \\
\hline $\begin{array}{l}\text { DeFina } 2011 \\
\text { (68) }\end{array}$ & USA & General population & $64(31 \%)$ & $64(31 \%)$ & $2500 / 500$ & 168 \\
\hline $\begin{array}{l}\text { Ebrahimi } 2009 \\
\text { (6) }\end{array}$ & Iran & General population & $47(15 \%)$ & $43(9 \%)$ & $180 / 120$ & 180 \\
\hline $\begin{array}{l}\text { Emsley } 2008 \\
\text { (69) }\end{array}$ & South Africa & $\begin{array}{l}\text { Community psychiatric } \\
\text { services and university } \\
\text { hospital }\end{array}$ & $39(69 \%)$ & $33(70 \%)$ & $2000 / 0$ & 84 \\
\hline Hill 2007 (70) & Australia & Unclear & $33(33 \%)$ & $32(41 \%)$ & Total 6000 & 84 \\
\hline $\begin{array}{l}\text { Itariu } 2012 \\
\text { (71) }\end{array}$ & Austria & Bariatric surgery clinic & $27(15 \%)$ & $28(18 \%)$ & $1840 / 1520$ & 56 \\
\hline $\begin{array}{l}\text { Kabir } 2007 \\
\text { (11) }\end{array}$ & France & $\begin{array}{l}\text { Diabetes department } \\
\text { outpatient clinic }\end{array}$ & $12(0 \%)$ & $14(0 \%)$ & $1080 / 720$ & 60 \\
\hline $\begin{array}{l}\text { Kunesova } \\
2006(28)\end{array}$ & $\begin{array}{l}\text { Czech } \\
\text { Republic }\end{array}$ & Unclear & $11(0 \%)$ & $9(0 \%)$ & Total 2800 & 21 \\
\hline $\begin{array}{l}\text { Marqués } 2008 \\
\text { (59) }\end{array}$ & Spain & $\begin{array}{l}\text { Follow up from } \\
\text { SEAFOODPlus } \\
\text { YOUNG Study }\end{array}$ & $14(100 \%)$ & $7(100 \%)$ & Total 1070 & 56 \\
\hline $\begin{array}{l}\text { Munro } 2012 \\
\text { (13) }\end{array}$ & Australia & General population & $18(17 \%)$ & $14(21 \%)$ & $420 / 1620$ & 98 \\
\hline $\begin{array}{l}\text { Munro } 2013 \\
\text { (12) }\end{array}$ & Australia & General population & $20(25 \%)$ & $19(21 \%)$ & $420 / 1620$ & 56 \\
\hline $\begin{array}{l}\text { Paniagua } \\
2011 \text { (8) }\end{array}$ & $\begin{array}{l}8 \text { European } \\
\text { countries }\end{array}$ & LIPGENE study & $83(48 \%)$ & $77(44 \%)$ & Total 1240 & 84 \\
\hline $\begin{array}{l}\text { Thorsdottir } \\
2007 \text { (18) }\end{array}$ & $\begin{array}{l}\text { Iceland, } \\
\text { Spain, } \\
\text { Ireland }\end{array}$ & $\begin{array}{l}\text { SEAFOODPlus } \\
\text { YOUNG Study }\end{array}$ & $244(43 \%)$ & $80(40 \%)$ & $\begin{array}{l}\text { Total: cod: } 300 \text {, } \\
\text { salmon: } 3000, \\
\text { capsules: } 1500\end{array}$ & 56 \\
\hline $\begin{array}{l}\text { Troseid } 2009 \\
(32) \dagger\end{array}$ & Norway & $\begin{array}{l}\text { Follow up from Oslo } \\
\text { Diet and Antismoking } \\
\text { Study | }\end{array}$ & $282(100 \%)$ & $281(100 \%)$ & $840 / 480$ & 1095 \\
\hline $\begin{array}{l}\text { Yamaoka } \\
2007 \text { (19) }\end{array}$ & Japan & $\begin{array}{l}\text { Female college } \\
\text { students }\end{array}$ & $57(0 \%)$ & $46(0 \%)$ & $0 / 700$ & 35 \\
\hline
\end{tabular}




\section{References}

1. Obesity: Preventing and Managing the Global Epidemic. Geneva: WHO. 2000.

2. Popkin BM. Global nutrition dynamics: the world is shifting rapidly toward a diet linked with noncommunicable diseases. Am J Clin Nutr. 2006;84(2):289-98.

3. Pischon T, Boeing H, Hoffmann K et al. General and abdominal adiposity and risk of death in Europe. N Engl J Med. 2008;359(20):2105-20.

4. Bjorge T, Engeland A, Tverdal A, Smith GD. Body mass index in adolescence in relation to cause-specific mortality: a follow-up of 230,000 Norwegian adolescents. Am J Epidemiol. 2008;168(1):30-7.

5. WHO. Obesity and overweight. http://www.who.int/mediacentre/factsheets/fs311/en/index.html 2008.

6. Ebrahimi M, Ghayour-Mobarhan M, Rezaiean S et al. Omega-3 fatty acid supplements improve the cardiovascular risk profile of subjects with metabolic syndrome, including markers of inflammation and auto-immunity. Acta Cardiol. 2009;64(3):321-7. omega 3 fatty acids, and risk of cerebrovascular disease: systematic review and metaanalysis. BMJ. 2012;345:e6698. supplemented with long-chain n-3 PUFA reduces the risk of the metabolic syndrome. Atherosclerosis. 2011;218(2):443-50. 
9. Jimenez-Gomez Y, Marin C, Perez-Martinez P et al. A low-fat, high-complex carbohydrate diet supplemented with long-chain (n-3) fatty acids alters the postprandial lipoprotein profile in patients with metabolic syndrome. J Nutr. 2010;140(9):1595-601.

10. Nkondjock A, Receveur O. Fish-seafood consumption, obesity, and risk of type 2 diabetes: an ecological study. Diabetes Metab. 2003;29(6):635-42.

11. Kabir M, Skurnik G, Naour $\mathrm{N}$ et al. Treatment for 2 mo with n-3 polyunsaturated fatty acids reduces adiposity and some atherogenic factors but does not improve insulin sensitivity in women with type 2 diabetes: A randomized controlled study. Am J Clin Nutr. 2007;86(6):1670-9.

12. Munro IA, Garg ML. Prior supplementation with long chain omega-3 polyunsaturated fatty acids promotes weight loss in obese adults: a double-blinded randomised controlled trial. Food Funct. 2013;4(4):650-8.

13. Munro IA, Garg ML. Dietary supplementation with n-3 PUFA does not promote weight loss when combined with a very-low-energy diet. Br J Nutr. 2012;108(8):1466-74.

14. Crochemore IC, Souza AF, de Souza AC, Rosado EL. omega-3 polyunsaturated fatty acid supplementation does not influence body composition, insulin resistance, and lipemia in women with type 2 diabetes and obesity. Nutr Clin Pract. 2012;27(4):553-60.

15. Buckley JD, Howe PR. Long-chain omega-3 polyunsaturated fatty acids may be beneficial for reducing obesity-a review. Nutrients. 2010;2(12):1212-30. Nutr. 2012;107 Suppl 2:S107-S116. 
17. Abete I, Parra D, Martinez JA. Legume-, fish-, or high-protein-based hypocaloric diets: Effects on weight loss and mitochondrial oxidation in obese men. J Med Food. 2009;12(1):100-8.

18. Thorsdottir I, Tomasson H, Gunnarsdottir I et al. Randomized trial of weight-loss-diets for young adults varying in fish and fish oil content. Int J Obes. 2007;31(10):1560-6.

19. Yamaoka S, Fujimoto M, Mori M, Mori H, Yamori Y. Risk reduction of lifestyle-related diseases in young adults on soy- or fish-rich traditional Japanese meals. Clin Exp Pharmacol Physiol. 2007;34:S79-S81.

20. Higgins JPTe, Green S. Cochrane Handbook for Systematic Reviews of Interventions. Chichester: Wiley. 2008.

21. Moher D, Liberati A, Tetzlaff J, Altman DG. Preferred reporting items for systematic reviews and meta-analyses: the PRISMA statement. PLoS Med. 2009;6(7):e1000097.

22. Dewey A, Baughan C, Dean T, Higgins B, Johnson I. Eicosapentaenoic acid (EPA, an omega-3 fatty acid from fish oils) for the treatment of cancer cachexia. Cochrane Database Syst Rev. 2007;(1):CD004597.

23. Colomer R, Moreno-Nogueira JM, Garcia-Luna PP et al. N-3 fatty acids, cancer and cachexia: a systematic review of the literature. Br J Nutr. 2007;97(5):823-31.

24. Makrides M, Duley L, Olsen SF. Marine oil, and other prostaglandin precursor, supplementation for pregnancy uncomplicated by pre-eclampsia or intrauterine growth restriction. Cochrane Database Syst Rev. 2006;3:CD003402. 
25. Makrides M, Gibson RA, Udell T, Ried K. Supplementation of infant formula with long-chain polyunsaturated fatty acids does not influence the growth of term infants. Am J Clin Nutr. 2005;81(5):1094-101.

26. Juni P, Altman DG, Egger M. Systematic reviews in health care: Assessing the quality of controlled clinical trials. BMJ. 2001;323(7303):42-6.

27. Juni P, Witschi A, Bloch R, Egger M. The hazards of scoring the quality of clinical trials for meta-analysis. JAMA. 1999;282(11):1054-60.

28. Kunesova M, Braunerova R, Hlavaty $\mathrm{P}$ et al. The influence of $n-3$ polyunsaturated fatty acids and very low calorie diet during a short-term weight reducing regimen on weight loss and serum fatty acid composition in severely obese women. Physiol Res. 2006;55(1):63-72.

29. Bays HE, Maki KC, Doyle RT, Stein E. The effect of prescription omega-3 fatty acids on body weight after 8 to 16 weeks of treatment for very high triglyceride levels. Postgrad Med. 2009;121(5):145-50.

30. Higgins JP, Thompson SG. Quantifying heterogeneity in a meta-analysis. Stat Med. 2002;21(11):1539-58.

31. Egger M, Davey-Smith G, Schneider M, Minder C. Bias in meta-analysis detected by a simple, graphical test. British Medical Journal. 1997;315(629):634.

32. Troseid M, Arnesen H, Hjerkinn EM, Seljeflot I. Serum levels of interleukin-18 are reduced by diet and n-3 fatty acid intervention in elderly high-risk men. Metab Clin Exp. 2009;58(11):1543-9. 
33. Williams CM, Burdge G. Long-chain n-3 PUFA: plant v. marine sources. Proc Nutr Soc. 2006;65(1):42-50.

34. Blackburn G. Effect of degree of weight loss on health benefits. Obes Res. 1995;3 Suppl 2:211s$6 s$.

35. Pasanisi F, Contaldo F, de SG, Mancini M. Benefits of sustained moderate weight loss in obesity. Nutr Metab Cardiovasc Dis. 2001;11(6):401-6.

36. Ross R, Bradshaw AJ. The future of obesity reduction: beyond weight loss. Nat Rev Endocrinol. 2009;5(6):319-25.

37. Klein S. Outcome success in obesity. Obes Res. 2001;9 Suppl 4:354S-8S.

38. Hotamisligil GS, Arner P, Caro JF, Atkinson RL, Spiegelman BM. Increased adipose tissue expression of tumor necrosis factor-alpha in human obesity and insulin resistance. J Clin Invest. 1995;95(5):2409-15.

39. Bastard JP, Jardel C, Bruckert E et al. Elevated levels of interleukin 6 are reduced in serum and subcutaneous adipose tissue of obese women after weight loss. J Clin Endocrinol Metab. 2000;85(9):3338-42.

40. Bastard JP, Maachi M, Van Nhieu JT et al. Adipose tissue IL-6 content correlates with resistance to insulin activation of glucose uptake both in vivo and in vitro. J Clin Endocrinol Metab. 2002;87(5):2084-9. 
41. Ramel A, Martinez A, Kiely M, Morais G, Bandarra NM, Thorsdottir I. Beneficial effects of long-chain n-3 fatty acids included in an energy-restricted diet on insulin resistance in overweight and obese European young adults. Diabetologia. 2008;51(7):1261-8.

42. Andersen G, Harnack K, Erbersdobler HF, Somoza V. Dietary eicosapentaenoic acid and docosahexaenoic acid are more effective than alpha-linolenic acid in improving insulin sensitivity in rats. Ann Nutr Metab. 2008;52(3):250-6.

43. Browning LM. n-3 Polyunsaturated fatty acids, inflammation and obesity-related disease. Proc Nutr Soc. 2003;62(2):447-53.

44. Rose G. Strategy of prevention: lessons from cardiovascular disease. Br Med J (Clin Res Ed). 1981;282(6279):1847-51.

45. Kohrt WM, Kirwan JP, Staten MA, Bourey RE, King DS, Holloszy JO. Insulin resistance in aging is related to abdominal obesity. Diabetes. 1993;42(2):273-81.

46. Seidell JC, Cigolini M, Charzewska J, Ellsinger BM, di BG. Fat distribution in European women: a comparison of anthropometric measurements in relation to cardiovascular risk factors. Int J Epidemiol. 1990;19(2):303-8.

47. Despres JP, Moorjani S, Lupien PJ, Tremblay A, Nadeau A, Bouchard C. Regional distribution of body fat, plasma lipoproteins, and cardiovascular disease. Arteriosclerosis. 1990;10(4):497-511.

48. Burdge GC, Wootton SA. Conversion of alpha-linolenic acid to eicosapentaenoic, docosapentaenoic and docosahexaenoic acids in young women. Br J Nutr. 2002;88(4):41120. 
49. Burdge GC, Jones AE, Wootton SA. Eicosapentaenoic and docosapentaenoic acids are the principal products of alpha-linolenic acid metabolism in young men*. Br J Nutr. 2002;88(4):355-63.

50. Crowe FL, Skeaff CM, Green TJ, Gray AR. Serum n-3 long-chain PUFA differ by sex and age in a population-based survey of New Zealand adolescents and adults. Br J Nutr. 2008;99(1):168-74.

51. Belzung F, Raclot T, Groscolas R. Fish oil n-3 fatty acids selectively limit the hypertrophy of abdominal fat depots in growing rats fed high-fat diets. Am J Physiol. 1993;264(6 Pt 2):R1111-R1118.

52. Ruzickova J, Rossmeisl M, Prazak T et al. Omega-3 PUFA of marine origin limit diet-induced obesity in mice by reducing cellularity of adipose tissue. Lipids. 2004;39(12):1177-85.

53. Ukropec J, Reseland JE, Gasperikova D et al. The hypotriglyceridemic effect of dietary n-3 FA is associated with increased beta-oxidation and reduced leptin expression. Lipids. 2003;38(10):1023-9.

54. Couet C, Delarue J, Ritz P, Antoine JM, Lamisse F. Effect of dietary fish oil on body fat mass and basal fat oxidation in healthy adults. International journal of obesity and related metabolic disorders : journal of the International Association for the Study of Obesity. 1997;21:637-43.

55. Baltzell JK, Wooten JT, Otto DA. Lipoprotein lipase in rats fed fish oil: apparent relationship to plasma insulin levels. Lipids. 1991;26(4):289-94. 
56. Fujihira E, Takahashi H, Nakazawa M. Effect of long-term feeding of taurine in hereditary hyperglycemic obese mice. Chem Pharm Bull (Tokyo). 1970;18(8):1636-42.

57. Camargo RL, Batista TM, Ribeiro RA, Velloso LA, Boschero AC, Carneiro EM. Effects of taurine supplementation upon food intake and central insulin signaling in malnourished mice fed on a high-fat diet. Adv Exp Med Biol. 2013;776:93-103.

58. Zhang M, Bi LF, Fang JH et al. Beneficial effects of taurine on serum lipids in overweight or obese non-diabetic subjects. Amino Acids. 2004;26(3):267-71.

59. Marqués M, Parra D, Kiely M, Bandarra N, Thorsdottir I, Martínez JA. [Omega-3 fatty acids inclusion as part of an energy restricted diet to improve the effect on blood lipids]. Medicina clínica. 2008;130:10-2.

60. Simopoulos AP. Evolutionary aspects of omega-3 fatty acids in the food supply. Prostaglandins Leukot Essent Fatty Acids. 1999;60(5-6):421-9.

61. Jew S, AbuMweis SS, Jones PJ. Evolution of the human diet: linking our ancestral diet to modern functional foods as a means of chronic disease prevention. J Med Food. 2009;12(5):925-34.

62. Stewart KM. Early hominid utilisation of fish resources and implications for seasonality and behaviour. Journal of Human Evolution. 1994;27:229-45.

63. Joordens JC, Wesselingh FP, de VJ, Vonhof HB, Kroon D. Relevance of aquatic environments for hominins: a case study from Trinil (Java, Indonesia). J Hum Evol. 2009;57(6):656-71. 
64. Jerardino A, Marean CW. Shellfish gathering, marine paleoecology and modern human behavior: perspectives from cave PP13B, Pinnacle Point, South Africa. J Hum Evol. 2010;59(3-4):412-24.

65. Bender R, Tobias PV, Bender N. The Savannah hypotheses: origin, reception and impact on paleoanthropology. Hist Philos Life Sci. 2012;34(1-2):147-84.

66. Erlandson JM. The archaeology of aquatic adaptations: paradigms for a new millennium. Journal of Archaeological Research. 2001;9(4):287-350.

67. Kuipers RS, Joordens JC, Muskiet FA. A multidisciplinary reconstruction of Palaeolithic nutrition that holds promise for the prevention and treatment of diseases of civilisation. Nutr Res Rev. 2012;25(1):96-129.

68. DeFina LF, Marcoux LG, Devers SM, Cleaver JP, Willis BL. Effects of omega-3 supplementation in combination with diet and exercise on weight loss and body composition. Am J Clin Nutr. 2011;93(2):455-62.

69. Emsley R, Niehaus DJH, Oosthuizen PP et al. Safety of the omega-3 fatty acid, eicosapentaenoic acid (EPA) in psychiatric patients: Results from a randomized, placebocontrolled trial. Psychiatry Res. 2008;161(3):284-91.

70. Hill AM, Buckley JD, Murphy KJ, Howe PRC. Combining fish-oil supplements with regular aerobic exercise improves body composition and cardiovascular disease risk factors. Am $J$ Clin Nutr. 2007;85(5):1267-74. 
487

488

489

490

491
71. Itariu BK, Zeyda M, Hochbrugger EE et al. Long-chain n-3 PUFAs reduce adipose tissue and systemic inflammation in severely obese nondiabetic patients: a randomized controlled trial. Am J Clin Nutr. 2012;96(5):1137-49. 
Fig. 1: Flow chart of study selection.

493

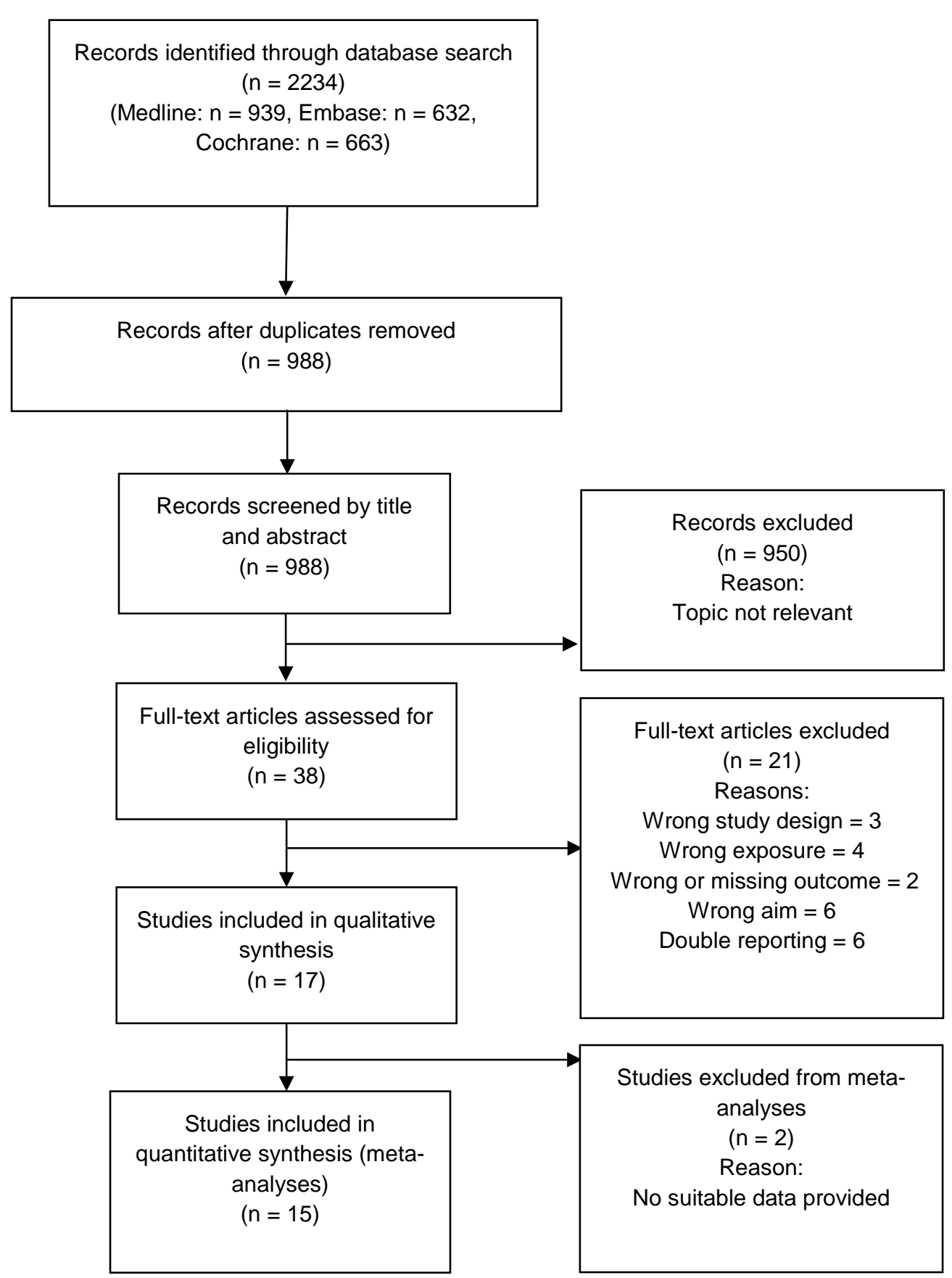


495 Fig 2: Results of meta-analyses performed for different outcomes on the association between fish or 496 fish oil intake and body composition.

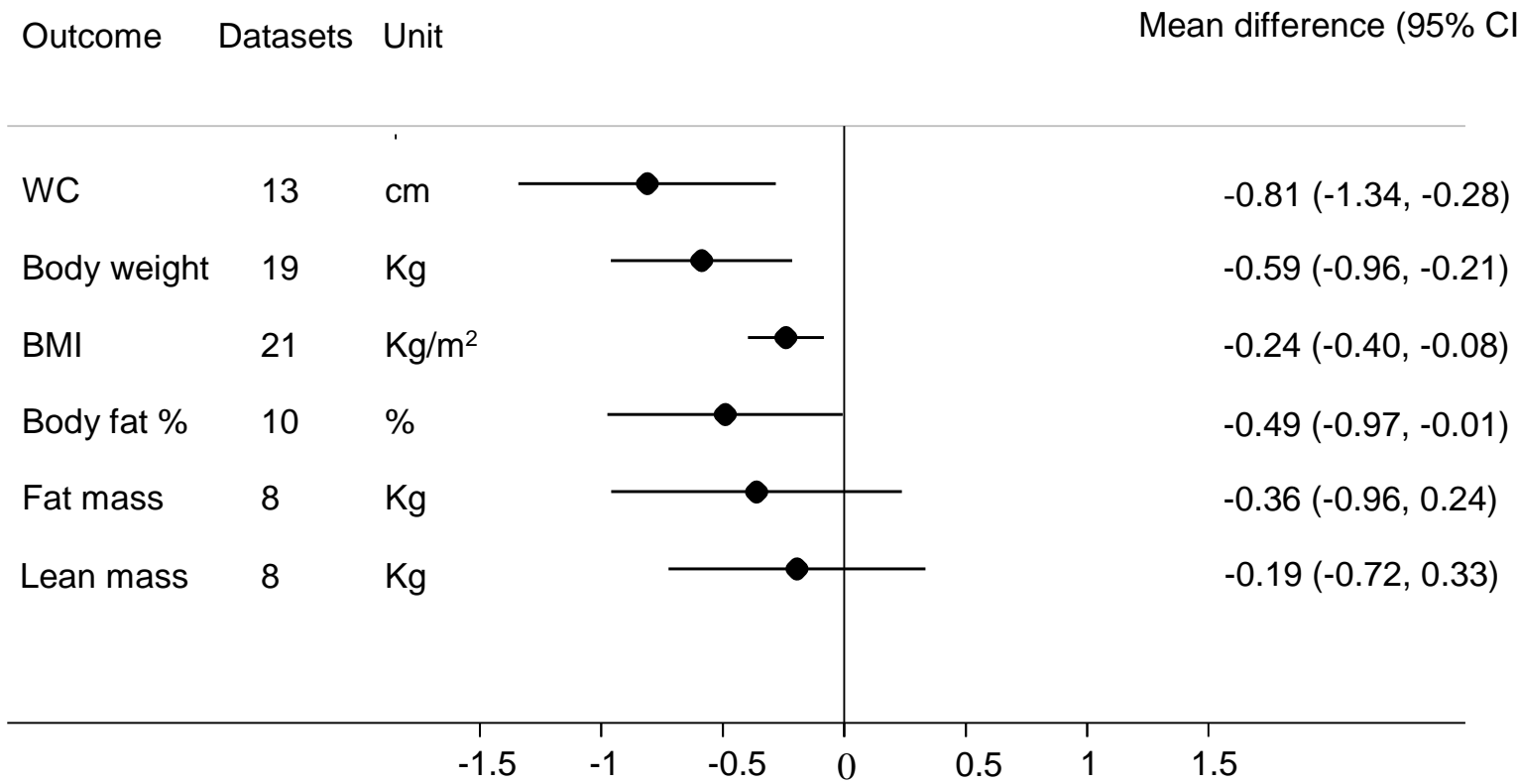

497

$498 \quad \mathrm{WC}=$ waist circumference, $\mathrm{BMI}=$ body mass index

499 
500 Fig. 3: Forest-plot on the association between fish or fish oil and BMI, by time of study duration.

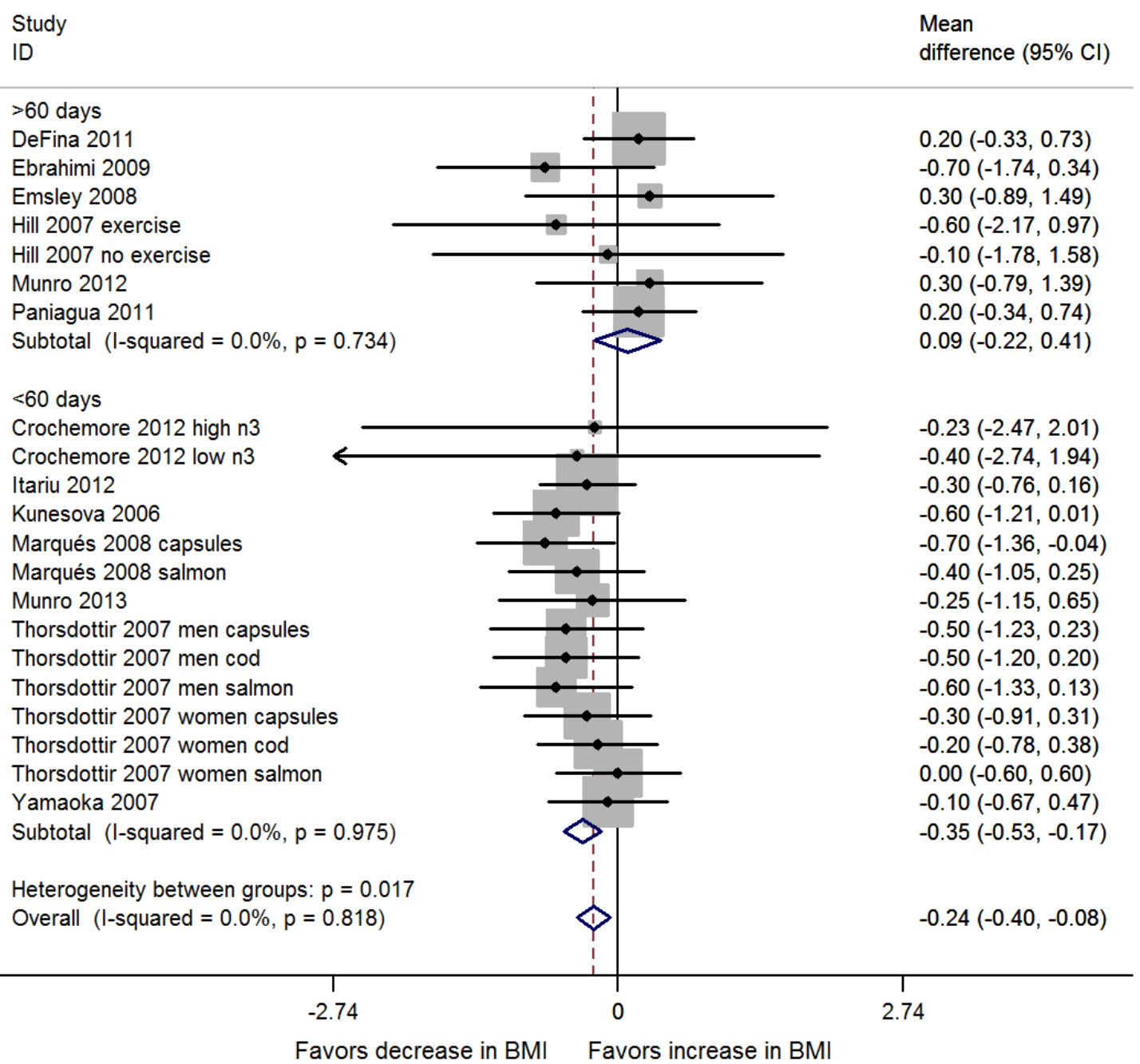


Table 1: Characteristics of studies

\begin{tabular}{|c|c|c|c|c|c|c|}
\hline Reference & Country & Setting or population & $\begin{array}{l}\text { Intervention } \\
\text { group (N, \% } \\
\text { males) }\end{array}$ & $\begin{array}{l}\text { Control } \\
\text { group }(\mathrm{N}, \\
\% \text { males })\end{array}$ & $\begin{array}{l}\text { Exposure, per } \\
\text { day }(\mathrm{mg}): \text { EPA / } \\
\text { DHA }\end{array}$ & $\begin{array}{l}\text { Duration of } \\
\text { study } \\
\text { (days) }\end{array}$ \\
\hline $\begin{array}{l}\text { Abete } 2009 \\
(17) \dagger\end{array}$ & Spain & General population & $8(100 \%)$ & $10(100 \%)$ & $\begin{array}{l}3 \text { meals with fatty } \\
\text { fish weekly }\end{array}$ & 56 \\
\hline $\begin{array}{l}\text { Bays 2009(29) } \\
\text { Crochemore } \\
2012(15)\end{array}$ & $\begin{array}{l}\text { USA } \\
\text { Brazil }\end{array}$ & $\begin{array}{l}\text { Unclear } \\
\text { Hospital, high blood } \\
\text { pressure and diabetes } \\
\text { program }\end{array}$ & $\begin{array}{l}84(71 \%) \\
28(0 \%)\end{array}$ & $\begin{array}{l}83(76 \%) \\
13(0 \%)\end{array}$ & $\begin{array}{l}1860 / 1500 \\
\text { A: } 547.5 / 352.5 \\
\text { B: } 328.5 / 211.5\end{array}$ & $\begin{array}{l}56 \\
30\end{array}$ \\
\hline $\begin{array}{l}\text { DeFina } 2011 \\
\text { (85) }\end{array}$ & USA & General population & $64(31 \%)$ & $64(31 \%)$ & $2500 / 500$ & 168 \\
\hline $\begin{array}{l}\text { Ebrahimi } 2009 \\
\text { (6) }\end{array}$ & Iran & General population & $47(15 \%)$ & $43(9 \%)$ & $180 / 120$ & 180 \\
\hline $\begin{array}{l}\text { Emsley } 2008 \\
\text { (86) }\end{array}$ & South Africa & $\begin{array}{l}\text { Community psychiatric } \\
\text { services and university } \\
\text { hospital }\end{array}$ & $39(69 \%)$ & $33(70 \%)$ & $2000 / 0$ & 84 \\
\hline Hill 2007 (87) & Australia & Unclear & $33(33 \%)$ & $32(41 \%)$ & Total 6000 & 84 \\
\hline $\begin{array}{l}\text { Itariu } 2012 \\
(88)\end{array}$ & Austria & Bariatric surgery clinic & $27(15 \%)$ & $28(18 \%)$ & $1840 / 1520$ & 56 \\
\hline $\begin{array}{l}\text { Kabir } 2007 \\
\text { (11) }\end{array}$ & France & $\begin{array}{l}\text { Diabetes department } \\
\text { outpatient clinic }\end{array}$ & $12(0 \%)$ & $14(0 \%)$ & 1080 / 720 & 60 \\
\hline $\begin{array}{l}\text { Kunesova } \\
2006(28)\end{array}$ & $\begin{array}{l}\text { Czech } \\
\text { Republic }\end{array}$ & Unclear & $11(0 \%)$ & $9(0 \%)$ & Total 2800 & 21 \\
\hline $\begin{array}{l}\text { Marqués } 2008 \\
\text { (89) }\end{array}$ & Spain & $\begin{array}{l}\text { Follow up from } \\
\text { SEAFOODPlus }\end{array}$ & $14(100 \%)$ & $7(100 \%)$ & Total 1070 & 56 \\
\hline $\begin{array}{l}\text { Munro } 2012 \\
\text { (14) }\end{array}$ & Australia & General population & $18(17 \%)$ & $14(21 \%)$ & $420 / 1620$ & 98 \\
\hline $\begin{array}{l}\text { Munro } 2013 \\
\text { (12) }\end{array}$ & Australia & General population & $20(25 \%)$ & $19(21 \%)$ & $420 / 1620$ & 56 \\
\hline $\begin{array}{l}\text { Paniagua } \\
2011 \text { (8) }\end{array}$ & $\begin{array}{l}8 \text { European } \\
\text { countries }\end{array}$ & LIPGENE study & $83(48 \%)$ & $77(44 \%)$ & Total 1240 & 84 \\
\hline $\begin{array}{l}\text { Thorsdottir } \\
2007 \text { (18) }\end{array}$ & $\begin{array}{l}\text { Iceland, } \\
\text { Spain, } \\
\text { Ireland }\end{array}$ & $\begin{array}{l}\text { SEAFOODPlus } \\
\text { YOUNG Study }\end{array}$ & $244(43 \%)$ & $80(40 \%)$ & $\begin{array}{l}\text { Total: cod: } 300 \text {, } \\
\text { salmon: } 3000, \\
\text { capsules: } 1500\end{array}$ & 56 \\
\hline $\begin{array}{l}\text { Troseid } 2009 \\
(32) \dagger\end{array}$ & Norway & $\begin{array}{l}\text { Follow up from Oslo } \\
\text { Diet and Antismoking } \\
\text { Study | }\end{array}$ & $282(100 \%)$ & $281(100 \%)$ & $840 / 480$ & 1095 \\
\hline $\begin{array}{l}\text { Yamaoka } \\
2007 \text { (19) }\end{array}$ & Japan & $\begin{array}{l}\text { Female college } \\
\text { students }\end{array}$ & $57(0 \%)$ & $46(0 \%)$ & $0 / 700$ & 35 \\
\hline
\end{tabular}

$\dagger=$ not included in meta-analyses. 
Table 2: Methodological quality of studies

\begin{tabular}{|c|c|c|c|c|c|c|}
\hline Reference & $\begin{array}{l}\text { Sequence } \\
\text { generation }\end{array}$ & $\begin{array}{l}\text { Concealment of } \\
\text { allocation }\end{array}$ & Blinding participants & $\begin{array}{l}\text { Blinding } \\
\text { investigator }\end{array}$ & $\begin{array}{l}\text { Blinding } \\
\text { outcome } \\
\text { assessor }\end{array}$ & ITT \\
\hline Abete 2009 & unclear & unclear & n. a. & n. a. & unclear & unclear \\
\hline Bays 2009 & unclear & unclear & yes & yes & unclear & unclear \\
\hline Crochemore 2012 & uclear & unclear & yes & no & no & unclear \\
\hline DeFina 2011 & unclear & unclear & yes & unclear & unclear & yes \\
\hline Ebrahimi 2009 & unclear & unclear & no & no & unclear & no \\
\hline Emsley 2008 & unclear & unclear & yes & yes & unclear & yes \\
\hline Hill 2007 & unclear & unclear & yes & unclear & unclear & no \\
\hline Itariu 2012 & yes & yes & n. a. & n. a. & unclear & yes \\
\hline Kabir 2007 & unclear & unclear & yes & yes & unclear & unclear \\
\hline Kunesova 2006 & unclear & unclear & yes & unclear & unclear & unclear \\
\hline Marqués 2008 & yes & unclear & n. a. & n. a. & unclear & unclear \\
\hline Munro 2012 & yes & yes & yes & yes & unclear & unclear \\
\hline Munro 2013 & yes & yes & yes & yes & unclear & unclear \\
\hline Paniagu 2011 & yes & yes & unclear & unclear & unclear & unclear \\
\hline Thorsdottir 2007 & unclear & unclear & n. a. & n. a. & unclear & unclear \\
\hline Troseid 2009 & yes & yes & yes & yes & unclear & unclear \\
\hline Yamaoka 2007 & unclear & unclear & n. a. & n. a. & unclear & unclear \\
\hline
\end{tabular}

$506 \mathrm{ITT}=$ intention-to-treat analysis performed; n. a. = non applicable. 